Article

\title{
Corporate Social Responsibility and Earnings Management: Moderating Impact of Economic Cycles and Financial Performance
}

\author{
Tiago Gonçalves ${ }^{1, *(1)}$, Cristina Gaio ${ }^{1}$ and André Ferro ${ }^{2}$ \\ 1 Advance/CSG, ISEG-Lisbon School of Economics \& Management, Universidade de Lisboa, \\ 1200-781 Lisboa, Portugal; cgaio@iseg.ulisboa.pt \\ 2 Deloitte Portugal, ISEG-Lisbon School of Economics \& Management, Universidade de Lisboa, \\ 1200-781 Lisboa, Portugal; andre.cardoso.ferro@deloitte.pt \\ * Correspondence: tiago@iseg.ulisboa.pt; Tel.: +351-213-925-800
}

Citation: Gonçalves, T.; Gaio, C.;

Ferro, A. Corporate Social

Responsibility and Earnings

Management: Moderating Impact of Economic Cycles and Financial Performance. Sustainability 2021, 13, 9969. https://doi.org/10.3390/ su13179969

Academic Editor: Ermanno C. Tortia

Received: 9 August 2021

Accepted: 1 September 2021

Published: 6 September 2021

Publisher's Note: MDPI stays neutral with regard to jurisdictional claims in published maps and institutional affiliations.

Copyright: (c) 2021 by the authors. Licensee MDPI, Basel, Switzerland. This article is an open access article distributed under the terms and conditions of the Creative Commons Attribution (CC BY) license (https:/ / creativecommons.org/licenses/by/ $4.0 /)$.

\begin{abstract}
This study analyses the relationship between earnings management and corporate social responsibility. To this end, we use a sample of 568 listed companies from the European Union between 2010 and 2018. We use discretionary accruals as the measure of earnings management, under the Modified Jones model. Corporate social responsibility is proxied by the Combined Environmental, Social and Governance Score from the ASSET4 database. We find a negative relation between earnings management and corporate social responsibility, suggesting that managers from more socially responsible companies have a more ethical behavior and, thus, financial reporting of higher quality. Additional analysis provides evidence that economic cycles and financial performance play important roles in the relation between earnings management and corporate social responsibility. During periods of crisis or of losses, the relationship is positive, suggesting that under unfavorable economic conditions, management makes opportunistic use of a sustainable company's status to manage earnings.
\end{abstract}

Keywords: corporate social responsibility; earnings management; discretionary accruals; ESG score

\section{Introduction}

Corporate Social Responsibility (CSR) has gained increasing importance over time. In fact, the European Commission [1] proposes, through the Directive 2016/2341, new regulations regarding sustainable investment disclosures and sustainability risks, based on environmental, social and governance (ESG) factors.

Financial reporting is the main source of information about companies, and earnings is the principal metric of financial performance used by investors and analysts [2,3]. Aware of this, managers are motivated to manage accounting numbers in order to deliver the expected short-term results [4]. In this sense, earnings management (EM) is the deliberate intervention of financial reporting management for the purpose of private gain [5]. Kaplan [6] characterizes EM as probably the most important ethical issue facing managers during the financial reporting process.

Although the increasing importance of both topics, little is known about the association between EM and CSR, and the scarce literature presents mixed results. Some authors find a negative relation between EM and CSR and argue that sustainable practices lead managers to behave more ethically, which translates into higher transparency and quality of reported earnings [7-16]. However, others find a positive relation [17-19], whereas some authors suggest that the relationship between EM and CSR is mixed, due to contextual factors such as the legal and political system or the level of investment in sustainable policies, setting aside their more ethical judgments $[7,20,21]$. The mixed evidence provided by previous literature calls for additional evidence, with more robust and updated data [22]. 
Thus, this study aims to contribute to the literature by analyzing the association between EM and CSR, using a sample of 3,444 listed companies from 17 European Union and European Free Trade Association (EFTA) countries, for the period from 2010 to 2018. The Modified Jones model [23], complemented by Kothari et al. [24], is used to calculate EM measure, and the combined ESG score from the ASSET4 database is used to measure CSR.

We can draw several conclusions from the results. First, they suggest that there is an inverse relationship between CSR and EM, meaning that socially responsible companies report more transparent financial information, and thus have higher quality financial reporting. The results are robust to alternative CSR measures, to different strategies of EM (increasing or decreasing earnings), as well as to moderate levels of sustainability investments. Second, the results suggest that when sustainable firms manage their earnings, they tend to adopt income-increasing strategies. Third, the economic crisis plays an important role in the relationship between EM and CSR. Although the relationship is negative across the years, in periods of crisis managers tend to adopt not income-increasing but income-decreasing strategies, probably to present better results in subsequent periods. Finally, our results also suggest that economic performance play also a role in the relation between CSR and EM. Indeed, it seems that more sustainable companies tend to practice more EM and adopt income-decreasing strategies in the years they report a loss.

We contribute to the literature in several ways: First, we provide additional evidence that contributes to tackling the mixed evidence regarding the relationship between CSR and EM. Secondly, we analyze geography (Europe) which is significantly less studied in the extant literature and exhibits institutional differences from US firms. Thirdly, we specifically address modeling issues in previous research relating to endogeneity in this relationship, by controlling our results in terms of the firm, year and business sector fixed effects. Finally, we argue and show that the CSR and EM relationship is not constant, (which reconciles and potentially explains previous mixed evidence), but is moderated by macroeconomic cycle conditions as well as firms' financial performance.

The paper proceeds as follows. We present the literature review and hypotheses in the next section. In the subsequent sections, we describe our research methods and the main results. Then we present results from additional analysis followed by the conclusions in the last section.

\section{Literature Review and Research Hypotheses}

Accounting earnings are the main accepted metric of financial performance [2,3] and one of the decisive criteria for investment [4]. In the view of managers, earnings play a more important informative role in financial reporting than, for example, cash flows [2,25-27]. Thus, managers are tempted to manage earnings in order to report the expected short-term results even at the expense of the long-term objective of maximizing the value of the firm $[26,28,29]$.

According to Činčalová et al. [30], p. 2, "the concept of CSR has no uniform definition, and there is still some confusion as to how CSR should be explained. CSR is about having responsibilities and taking actions beyond their legal obligations and business aims. It covers economic, social, environmental, and philanthropic activities".

Ehsan et al. [31] state that an inverse relationship between CSR and EM predominates. Managers seek to establish strong and healthy relationships with stakeholders in order to serve their interests and enhance ethical and moral values against EM practices [11,16,32]. Hong and Andersen [9] and Kim et al. [10] base their studies on US firms and conclude that the relationship between CSR and EM is negative, i.e., sustainability-oriented firms provide more transparent financial information, practicing less aggressive EM. Hong and Andersen [9] also demonstrate that maintaining long-term relationships with the largest number of stakeholders enables sustainable growth, even if it implies an agency cost in relation to short-term profit objectives. Calegari et al. [8] study a sample of North American companies and show that CSR increases the quality of the earnings, that is, negatively impacts EM. The authors further state that CSR generates an indirect but positive effect 
on firm value. Consistently, several authors [12,14,33] argue that socially responsible firms are less likely to manage results. Extant literature provides, also, empirical evidence that firms with higher ethical standards enable them to improve the quality of reported results, increase firm value and create value for all stakeholders [7,34]. Chih et al. [7] and Scholtens and Kang [13] further argue that in countries where the level of investor protection is high, managers practice more CSR activities, providing higher quality financial reporting disclosure.

Contrarily, Salewski and Zülch [19] highlight that the relationship between CSR and EM is positive. They find that investment and disclosure of CSR practices do not necessarily imply an increase in the quality of financial reporting of European companies. The authors also provide evidence that companies with high sustainability indices are more likely to exercise EM and report lower quality earnings. Prior et al. [18], based on an international sample, argue that managers who practice EM use socially responsible practices to gain stakeholder support, concluding that sustainability-related activities are a powerful tool to gain support from users of financial information. When managers need to protect their personal interests, they use social practices to justify their discretionary judgments on earnings, undermining long-term value creation. Similarly, Gargouri et al. [17] show that Canadian companies use CSR in a biased way to hide bad accounting practices. They argue that the environmental and social aspects positively affect the relationship between CSR and EM since the implementation of environmental projects and social practices leads to a significant increase in discretionary spending, that is, it leads to more EM, negatively affecting the company's financial performance.

On the other hand, Chih et al. [7] investigate the link between CSR and EM, using an international sample and argue that if firms seek to maintain financial transparency, they should avoid profit smoothing. However, when managers seek to satisfy multiple stakeholder objectives, financial performance may be negatively affected, and management may be persuaded to use EM practices. Thus, the relationship appears to be inverse for moderate levels of sustainability, and when companies seek to ostensibly implement CSR measures, the relationship becomes positive, i.e., managers manage earnings in order to meet social, environmental and economic objectives. In line with this view, Kyaw et al. [21], based on a sample of European countries, suggest that in countries where institutional contexts allow CSR measures to be included implicit in company policies, sustainable practices may serve a purpose other than the ethical expectations of stakeholders. More specifically, CSR serves as a tool to hide EM practices. Yip et al. [20] study a sample consisting of firms in the oil and gas industry and the food industry. For the oil and gas industry, the empirical evidence suggests a negative relation between EM and CSR, while in the food industry there seems to be evidence of a positive one, suggesting industry characteristics may influence the relation between CSR and EM.

According to the integrative and ethical theories of CSR and the studies of Hong and Andersen [9], Kim et al. [10] and Pyo and Lee [12], we expect that companies that practice more CSR disclose more transparent financial information, practice less EM and so report higher earnings quality. Therefore, our first hypothesis is:

Hypothesis 1 (H1). The relationship between EM and CSR is negative.

Following the studies of Chih et al. [7] and Kyaw et al. [21], companies practice less EM when they seek to be transparent and report earnings of quality. However, when practiced sustainable policies are above average, managers tend to manage more earnings, since CSR instruments may cover up less transparent practices in financial reporting (e.g., green-washing phenomenon). In this sense, the second hypothesis is developed as follows:

Hypothesis 2 (H2). For high levels of CSR, the marginal relationship between EM and CSR is positive. 
Periods of economic crisis can constraint CSR practices [35]. Kyaw et al. [21] argue that during this period, more sustainable companies practice more EM in order to justify spending allocation. In this way, CSR serves as an instrument to cover up EM, in periods of crisis.

Hypothesis 3 (H3). In periods of economic crisis, the relationship between EM and CSR management is positive.

Waddock and Graves [36], Roman et al. [37] and Orlitzky et al. [38] state that social performance is positively related to firm performance, that is, the more companies incorporate sustainable practices in their business models, the better their financial performance will be. However, Roychowdhury [39] states that when socially responsible companies obtain results that fall short of those expected, they practice more EM, in the sense of saving them for subsequent periods.

Hypothesis 4 (H4). In periods of reported losses, the relationship between EM and CSR is positive.

\section{Research Method}

\subsection{Data and Sample Selection}

Accounting and financial data were collected from Bureau Van Dijk's Amadeus database, while data on CSR were collected from Thomson Reuters' ASSET4. The sample data corresponds to a period of 9 years, from 2010 to 2018.

First, all listed companies in the European Union and EFTA with available accounting, financial and CSR data were selected, with the exception of companies in the financial sector and public administration institutions, as they are subject to a specific accounting and regulatory system. The initial sample size is 6333 firm-year observations. Then, Swiss companies were excluded as they are not required to present their accounting figures under International Financial Reporting Standards (IFRS). Additionally, firms with insufficient information needed to calculate accruals-based EM metrics, as well as sectors and countries with fewer than six firm-year observations were excluded [40]

Subsequently, to eliminate the effects caused by outliers, accounting data whose values lie below the 1st percentile and above the 99th percentile were excluded. Therefore, the final sample consists of 568 companies, belonging to 17 European Union and EFTA countries and 12 activity sectors, corresponding to 3444 firm-year observations.

Appendix A, Tables A1 and A2 present the composition of the sample by country and by industry, respectively. The most represented countries are Germany, France and the United Kingdom, with $14.14 \%, 15.36 \%$ and $42.07 \%$ of the total, respectively. In terms of industry, the most represented are the manufacturing sector $(\mathrm{C})$ and the professional, scientific and technical activities sector (M), with $23.24 \%$ and $28.66 \%$ of the total sample, respectively.

\subsection{Earnings Management and Corporate Social Responsibility Measures}

Earnings have two components: accruals and cash flows. Our measure of EM is based on discretionary accruals computed by the modified Jones model by Dechow et al. [41] and complemented by Kothari et al. [24]. Kothari et al. [24] incorporate in the model return on assets (ROA), as a variable to measure the impact of company performance on discretionary accruals, as well as a constant term, which allows for additional control of cross-sectional heteroskedasticity.

We start by computing total accruals for each firm as follows:

$$
\text { Accruals }_{i, t}=\Delta C A_{i, t}-\Delta C L_{i, t}-\Delta C a s h_{i, t}+\Delta S \operatorname{Debt}_{i, t}-\operatorname{Dep}_{i, t}
$$

where $\triangle C A i, t$ corresponds to the change in current assets between period $t-1$ and $\mathrm{t}$ for firm $i ; \Delta C L i, t$ represents the change in current liabilities between period $t-1$ and $\mathrm{t}$ for firm $i$; $\Delta$ Cashi, $t$ corresponds to the change in cash and cash equivalents between period $t-1$ and $t$ for firm $i$; $\Delta$ SDebti,t is the change in short-term debt included in current liabilities 
between period $t-1$ and $\mathrm{t}$ for firm $i$; Depi, $t$ represents depreciation and amortization for period $\mathrm{t}$ for firm $i$.

Then, we estimate regression 2 in order to calculate the discretionary accruals for each sector and year:

$$
\frac{\text { Accruals }_{i, t}}{T A_{i, t-1}}=\beta_{0}+\beta_{1}\left(\frac{1}{T A_{i, t-1}}\right)+\beta_{2}\left(\frac{\Delta \operatorname{Rev}_{i, t}-\Delta \operatorname{Rec}_{i, t}}{T A_{i, t-1}}\right)+\beta_{3}\left(\frac{P P E_{i, t}}{T A_{i, t-1}}\right)+\beta_{4}\left(R O A_{i, t-1}\right)+e_{i, t}
$$

where $T A_{i, t-1}$ corresponds to total assets in period $t-1$ for firm $i$; $\Delta e v_{i, t}$ represents the change in sales between period $t-1$ and $t$ for firm i; $\Delta R e c_{i, t}$ represents the change in accounts receivable between period $t-1$ and $t$ for firm $i$; $P P E_{i, t}$ corresponds to property, plant and equipment in period $\mathrm{t}$ for firm $i$; $R O A_{i, t-1}$ represents the return on assets in period $t-1$ for firm $i$; $e_{i, t}$ corresponds to the residuals obtained between the value estimated by the model and the actual value in period $\mathrm{t}$ for firm $i$ and it is our measure of discretionary accruals:

$$
\text { AccDis }=e_{i, t}
$$

The higher the residual value, the greater is the income-increasing EM. However, not only the direction but also the intensity of EM is important for this study. Thus, the magnitude of EM is calculated through the absolute value of the residuals in Equation (2):

$$
\text { AccDis_Abs }=\left|e_{i, t}\right|
$$

The higher the value of the residuals in absolute value, the lower the quality of the reported accruals, and consequently, the higher the level of EM.

According to Gargouri et al. [17], corporate social responsibility is measured from the weighting between environmental, social and corporate governance (ESG) metrics. Following the studies of Kyaw et al. [21], the ASSET4 database from Thomson Reuters presents one of the most comprehensive databases on ESG performance (ESG_score) from over 7000 public companies since 2002.

The ESG_score is constructed from the following 10 categories: resource use; emissions; innovation; workforce; human rights; community; product responsibility; management level; shareholders; CSR strategy. The methodology adopted consists of attributing a percentile ranking, that is, each company is attributed a ranking based on its performance in each category, compared to the performance of the other companies. After the attribution of the rank, the score is calculated based on three factors: how many companies are worse than the current one; how many companies have the same value; how many companies have some value. After calculating the score per category, the ESG_score is obtained by weighting each category.

Besides the ESG_score, another measure based on controversies related to the company (Controversy_score) is calculated. If during the year, the company is involved in any scandal or related denigrating news (e.g., lawsuit, human rights violation, fine or fine), the controversy score is affected. The impact of the event may also affect subsequent periods. The methodology adopted to calculate the Controversy_score is equal to the ESG_score. A low Controversy_score translates into more controversies related to the company.

Based on these two scores, a combined ESG score (Combined_score) is calculated, which aggregates the environmental, social and corporate governance information, adjusted by the controversies captured by the international media sources. The main objective of the combined score is to adjust all the company's media facts to the ESG performance.

To test our hypotheses, the following model is analyzed: 
EM is analyzed in magnitude (AccDis_Abs) and in direction (AccDis). The independent variable of interest CSR represents the level of corporate social responsibility, measured through Combined_Score.

To avoid the problem of correlated omitted variables, control variables that may affect financial reporting behavior and the level of CSR performance were included. Roychowdhury [39] suggests that growth opportunity and firm size may explain some of the variations in EM. The variable growth represents the firm's growth, calculated using the ratio of the percentage change in sales in the period $t-1$ to $t$. Size variable represents the firm size, measured by the natural logarithm of total assets. Press and Weintrop [42] indicate that the level of indebtedness is correlated with EM. Companies with a strong dependence on external financing present higher levels of information disclosure since they are subject to greater scrutiny. Lev variable represents the level of leverage of the company, calculated through the ratio between the sum of short- and long-term debt by total assets. In turn, Carlson and Bathala [43] state that company performance is correlated with the level of EM. The ROA variable represents the return on assets, measured through the ratio of net income to total assets. Becker et al. [44] show that EM may differ according to the scrutiny performed by large audit firms. The Big4 dummy variable takes the value 1 if the firm is audited by one of the Big 4 and 0 otherwise. The level of accruals can change over time and across countries, thus leading to endogeneity issues. As such, we control for these effects by using year and country fixed effects as well as firms clustered robust errors.

\section{Results and Discussion}

\subsection{Descriptive Statistics}

Table 1 presents the descriptive statistics of the variables included in the model. The average level of discretionary accruals is -0.0425 , which means that, on average, managers manage earnings downward. On average, the European companies under study have an ESG score of 0.5928 , a controversial score of 0.4467 , a combined score of 0.5174 , an annual sales growth rate of $6.62 \%$ and a size close to 7.689 million euros, a debt level of $22.74 \%$ and return on assets of $5.42 \%$. Finally, $77.93 \%$ of the companies in the sample are audited by a Big Four firm.

Table 1. Descriptive Statistics.

\begin{tabular}{ccccccc}
\hline Variables $^{1}$ & Obs. & Mean & Median & Std. Dev & Minimum & Maximum \\
\hline AccDis & 3444 & -0.0425 & 0.0025 & 0.2484 & -3.7200 & 0.5071 \\
AccDis_Abs & 3444 & 0.1341 & 0.0834 & 0.2134 & 0.0001 & 3.7200 \\
ESG_Score & 3444 & 0.5928 & 0.6048 & 0.1652 & 0.0029 & 0.9582 \\
Controversy_Score & 3444 & 0.4467 & 0.5717 & 0.2364 & 0.0002 & 0.7444 \\
Combined_Score & 3444 & 0.5174 & 0.5048 & 0.1613 & 0.0029 & 0.9352 \\
Growth & 3444 & 0.0662 & 0.0488 & 0.1722 & -0.4686 & 1.2658 \\
Size & 3444 & 6.6450 & 6.5977 & 0.6841 & 4.4096 & 8.6255 \\
Lev & 3444 & 0.2274 & 0.2186 & 0.1648 & 0.0000 & 0.9885 \\
ROA & 3444 & 0.0542 & 0.0480 & 0.0615 & -0.1804 & 0.2950 \\
\hline
\end{tabular}

${ }^{1}$ Detailed variable definitions are outlined in the Empirical Model section.

Apart from the CSR measures, that are significant and highly correlated with each other, the Pearson's correlations among the variables are low, suggesting that there is no multicollinearity in the data, which is confirmed with the variance inflation factors that are lower than 10 (results not tabulated).

\subsection{Corporate Social Responsibility and Earnings Management}

Table 2 presents the results of unbalanced panel data regressions, with year and country fixed effects, of the association between the EM and CSR. Columns (1) and (2) show the results in terms of intensity (AccDis_Abs) and direction (AccDis), respectively. 
Table 2. Corporate Social Responsibility and Earnings Management.

\begin{tabular}{|c|c|c|c|c|}
\hline Variables & (1) AccDis_Abs & (2) AccDis & (3) AccDis $<0$ & (4) AccDis $>0$ \\
\hline Combined_Score & $\begin{array}{c}-0.1181^{* * *} \\
(-5.566)\end{array}$ & $\begin{array}{c}0.1860 * * * \\
(8.210)\end{array}$ & $\begin{array}{c}-0.195^{* * *} \\
(-4.726)\end{array}$ & $\begin{array}{c}0.0212 * * \\
(2.022)\end{array}$ \\
\hline Growth & $\begin{array}{c}0.0517 * * \\
(2.558)\end{array}$ & $\begin{array}{c}-0.0478 * * \\
(-2.216)\end{array}$ & $\begin{array}{c}0.1524^{* * *} \\
(3.986)\end{array}$ & $\begin{array}{l}-0.0024 \\
(-0.241)\end{array}$ \\
\hline Size & $\begin{array}{c}-0.1027^{* * *} \\
(-18.687)\end{array}$ & $\begin{array}{c}0.1472 * * * \\
(25.087)\end{array}$ & $\begin{array}{c}-0.1944^{* * *} \\
(-16.806)\end{array}$ & $\begin{array}{l}-0.0052 * \\
(-1.735)\end{array}$ \\
\hline Lev & $\begin{array}{l}-0.044 * \\
(-1.937)\end{array}$ & $\begin{array}{c}0.1249^{* * *} \\
(5.154)\end{array}$ & $\begin{array}{c}-0.1083^{* * *} \\
(-2.585)\end{array}$ & $\begin{array}{c}0.0707^{* * *} \\
(6.039)\end{array}$ \\
\hline ROA & $\begin{array}{c}0.3322^{* * *} \\
(5.617)\end{array}$ & $\begin{array}{c}-0.6919^{* * *} \\
(-10.958)\end{array}$ & $\begin{array}{c}0.4611^{* * * *} \\
(4.778)\end{array}$ & $\begin{array}{c}-0.0656^{*} \\
(-1.729)\end{array}$ \\
\hline BIG4 & $\begin{array}{l}-0.0138 \\
(-1.135)\end{array}$ & $\begin{array}{l}0.0098 \\
(0.756)\end{array}$ & $\begin{array}{l}-0.0036 \\
(-0.168)\end{array}$ & $\begin{array}{c}-0.0213 * * * \\
(-3.310)\end{array}$ \\
\hline Constant & $\begin{array}{c}0.8713^{* * *} \\
(17.167)\end{array}$ & $\begin{array}{c}-1.0258^{* * *} \\
(-18.932)\end{array}$ & $\begin{array}{c}1.4341^{* * *} \\
(5.456)\end{array}$ & $\begin{array}{c}0.1235^{* * *} \\
(4.902)\end{array}$ \\
\hline Observations & 3444 & 3444 & 1682 & 1762 \\
\hline Adjusted R2 & 0.1772 & 0.3082 & 0.2644 & 0.0578 \\
\hline F-test & 25.72 & 52.12 & 21.14 & 4.60 \\
\hline$p$-value & 0.0000 & 0.0000 & 0.0000 & 0.0000 \\
\hline
\end{tabular}

The $t$-test statistic is in parentheses. ${ }^{*}{ }^{* *}$ and ${ }^{* * *}$ indicate significance level at $10 \%, 5 \%$ and $1 \%$, respectively. Detailed variable definitions are outlined in Empirical Model section.

To further analyze the association between EM direction and CSR, we split the sample into two groups: companies that manage earnings downward $($ AccDis $<0)$ and companies that manage earnings upward (AccDis $>0$ ), in terms of magnitude and report the results in Table 2, columns (3) and (4), respectively.

In terms of EM intensity, Combined_Score has a negative and statistically significant coefficient $(p$-value $<0.01)$, suggesting that more socially responsible companies have lower levels of EM. These results are in line with the studies of Chih et al. [7], Calegari et al. [8], Hong and Andersen [9], Kim et al. [10], Choi et al. [33], Pyo and Lee [12], Scholtens and Kang [13], Bozzolan et al. [14] and Cho and Chun [16], who argue that more socially responsible companies report more transparent financial information, and so, higher financial reporting quality. Thus, hypothesis $\mathrm{H} 1$ is validated.

With regard to the control variables, only BIG4 is not statistically significant, probably because of the composition of the sample, since about $78 \%$ of the companies are audited by one of the Big Four.

Growth presents a positive and statistically significant coefficient, suggesting that firms with higher growth opportunities are under pressure to stay in the capital market and thus practice more EM, as Skinner and Sloan [45] and Van Tendeloo and Vanstraelen [46] advocate. ROA presents also a positive and statistically significant association which is in line with Carlson and Barthala [43], who argue that companies with higher financial performance practice more EM.

Size and Lev have negative and statistically significant coefficients, suggesting that larger and more indebted firms practice less EM. These results are consistent with prior literature results that larger firms [47] and more leveraged firms [44,48] manage less earnings as they are subject to greater stakeholder scrutiny.

In terms of EM direction, Combined_Score has a positive and statistically significant coefficient of $1 \%$, suggesting that companies with more sustainable practices tend to use income-increasing strategies. This result is in line with Gargouri et al. [17] and Kyaw et al. [21], who argue that managers use CSR in order to cover up EM practices, considering CSR as an explanatory factor of positive results.

Again, control variables are statistically significant, except BIG4. Results suggest that larger companies with lower growth opportunities, more leveraged and with lower financial performance manage earnings upward. 
In addition, since the Combined_Score variable is affected by media news related to the company, we replace Combined_Score with ESG_Score, used by Kyaw et al. [21], and re-estimated both regressions in order to have the exclusive effect of CSR. Results (not tabulated) are similar to those report in Table 2, suggesting that more socially responsible companies have lower levels of EM and tend to manage earnings upward.

In terms of the magnitude of income-increasing and decreasing, Combined_Score presents a negative coefficient in column (3) and a positive coefficient in column (4), suggesting that more sustainable companies have lower income-decreasing EM but higher income-increasing EM. Taking together, these results confirm our main conclusion: when companies with more sustainable practices manage earning they tend to use incomeincreasing strategies.

\subsection{Impact of the Crisis on the Relation between Corporate Social Responsibility and Earnings Management ${ }^{*}$}

Further analysis is conducted in an attempt to understand how the financial crisis impacts the relationship between EM and CSR. Cheney and McMillan [35] state that during periods of financial crisis, companies act in a conservative and defensive manner. Thus, a crisis dummy variable, Crisis, is inserted into the base model, which assumes the value 1 if the observation belongs to the crisis period (years 2010 to 2012) and 0 otherwise. The Comb_Crisis variable is also added, to study the interaction between the Combined_Score and Crisis variables. Table 3, Panel A, presents the results obtained regarding the magnitude and direction of EM, columns (1) and (2), respectively.

Table 3. Corporate Social Responsibility and Earnings Management: Periods of Crisis and Loss.

\begin{tabular}{|c|c|c|c|c|}
\hline \multirow[b]{2}{*}{ Variables } & \multicolumn{2}{|c|}{ Panel A } & \multicolumn{2}{|c|}{ Panel B } \\
\hline & (1) AccDis_Abs & (2) AccDis & (3) AccDis_Abs & (4) AccDis \\
\hline Combined_Score & $\begin{array}{c}-0.1557^{* * *} \\
(-6.135)\end{array}$ & $\begin{array}{c}0.2301 * * * \\
(8.495)\end{array}$ & $\begin{array}{c}-0.1320^{* * *} \\
(-5.917)\end{array}$ & $\begin{array}{c}0.2047^{* * *} \\
(8.603)\end{array}$ \\
\hline Comb_Crisis & $\begin{array}{c}0.1195^{* * *} \\
(2.693)\end{array}$ & $\begin{array}{c}-0.1403^{* * *} \\
(-2.961)\end{array}$ & & \\
\hline Crisis & $\begin{array}{c}-0.1192^{* * *} \\
(-3.107)\end{array}$ & $\begin{array}{c}0.1265^{* * *} \\
(3.088)\end{array}$ & & \\
\hline Comb_Loss & & & $\begin{array}{c}0.1427 * * \\
(2.117)\end{array}$ & $\begin{array}{c}-0.1900 * * * \\
(-2.641)\end{array}$ \\
\hline Loss & & & $\begin{array}{l}-0.0075 \\
(-0.206)\end{array}$ & $\begin{array}{l}0.0208 \\
(0.531)\end{array}$ \\
\hline Growth & $\begin{array}{c}0.0517^{* *} \\
(2.563)\end{array}$ & $\begin{array}{c}-0.0478^{* *} \\
(-2.221)\end{array}$ & $\begin{array}{c}0.0569 * * * \\
(2.822)\end{array}$ & $\begin{array}{c}-0.0538^{* *} \\
(-2.503)\end{array}$ \\
\hline Size & $\begin{array}{c}-0.1029^{* * *} \\
(-18.730)\end{array}$ & $\begin{array}{c}0.1474^{* * *} \\
(25.145)\end{array}$ & $\begin{array}{c}-0.0987^{* * *} \\
(-17.834)\end{array}$ & $\begin{array}{c}0.1424^{* * *} \\
(24.141)\end{array}$ \\
\hline Lev & $\begin{array}{l}-0.0425^{*} \\
(-1.872)\end{array}$ & $\begin{array}{c}0.1231^{* * *} \\
(5.086)\end{array}$ & $\begin{array}{l}-0.0395^{*} \\
(-1.744)\end{array}$ & $\begin{array}{c}0.1200 * * * \\
(4.964)\end{array}$ \\
\hline ROA & $\begin{array}{c}0.3346^{* * *} \\
(5.662)\end{array}$ & $\begin{array}{l}-0.6947^{* * *} \\
(-11.014)\end{array}$ & $\begin{array}{c}0.5318^{* * *} \\
(7.309)\end{array}$ & $\begin{array}{c}-0.9236^{* * *} \\
(-11.901)\end{array}$ \\
\hline BIG4 & $\begin{array}{l}-0.0140 \\
(-1.154)\end{array}$ & $\begin{array}{l}0.0100 \\
(0.776)\end{array}$ & $\begin{array}{l}-0.0127 \\
(-1.053)\end{array}$ & $\begin{array}{l}0.0084 \\
(0.655)\end{array}$ \\
\hline Constant & $\begin{array}{c}0.9485^{* * *} \\
(16.289)\end{array}$ & $\begin{array}{l}-1.1029 * * * \\
(-17.747)\end{array}$ & $\begin{array}{c}0.8350 * * * \\
(16.289)\end{array}$ & $\begin{array}{c}-0.9841^{* * * *} \\
(-18.000)\end{array}$ \\
\hline Observations & 3444 & 3444 & 3444 & 3444 \\
\hline Adjusted R2 & 0.1787 & 0.3097 & 0.1833 & 0.3147 \\
\hline F-test & 25.17 & 50.84 & 25.16 & 50.40 \\
\hline$p$-value & 0.0000 & 0.0000 & 0.0000 & 0.0000 \\
\hline
\end{tabular}

The $t$-test statistic is in parentheses. ${ }^{*}{ }^{* *}$ and ${ }^{* * *}$ indicate significance level at $10 \%, 5 \%$ and $1 \%$, respectively. Detailed variable definitions are outlined in Empirical Model section. 
In terms of EM intensity, Crisis presents a negative and statistically significant coefficient, which indicates that, in the period of economic crisis, managers practice less EM, corroborating the studies of Filip and Raffournier [49]. The coefficient of the Combined_Score variable is also negative and statistically significant, suggesting that socially responsible companies practice less EM, as verified in the first hypothesis. However, the Comb_Crisis presents a positive and statistically significant coefficient, which indicates that in crisis years, companies with more CSR activities practice more EM than in boom years, suggesting that investors, by expecting higher levels of EM, reduce scrutiny to financial reports. This result is in line with the findings of Kyaw et al. [21] and hypothesis H3 is validated.

Regarding the EM direction, the coefficient of the Combined_Score is positive and statistically significant. These results are in line with the idea that companies with more sustainable practices engage in income-increasing EM. However, the Comb_Crise presents a negative and statistically significant coefficient, which indicates that during years of economic crisis, more sustainable companies manage their results with the aim of decreasing them, that is, in a logic of allocating costs in years of crisis and saving the results for better economic periods.

\subsection{Impact of Income Losses on the Relation between Corporate Social Responsibility and Earnings Management}

In order to analyze the impact of reporting losses may have on the relationship between EM and social practices, two new variables are added to the original model: a dummy variable Loss, which assumes the value 1 if the company reported a loss during a given year and 0 otherwise, and the variable Comb_Loss, which introduces the interaction between the Combined_Score and Loss. Table 3, Panel B, presents the results.

In terms of EM intensity, the coefficient of the Combined_Score variable is negative and statistically significant indicating that socially responsible companies practice less EM. With regard to the Comb_Loss variable, the coefficient is positive and statistically significant, suggesting that socially responsible firms that report losses practice more EM than those that report profits, corroborating with hypothesis H4.

In terms of EM direction, the coefficient of the Combined_Score variable is positive and statistically significant, suggesting that companies with more sustainable practices tend to manage earnings upward. The coefficient of the Comb_Loss is negative, suggesting that that in periods of financial loss, more sustainable companies practice income-decreasing strategies, probably with the intent of saving results for subsequent periods.

\subsection{Earnings Management in Companies with More and Less Sustainable Practices}

To further analyze the association between CRS and EM, additional tests are run by dividing the sample into companies with a Combined Score below (Panel A) and above (Panel B) the mean. Table 4 reports the results considering both EM intensity, columns (1) and (3), and EM direction, columns (2) and (4).

In terms of EM intensity, Combined_Score presents a negative and statistically significant coefficient in the subsample of companies with a score below the mean, suggesting that companies with moderate CSR practices have a lower level of EM, consistent with Chih et al. [7]. However, the coefficient of the Combined_Score, despite being negative, is not statistically significant in the subsample of companies that invest more in CSR activities. Therefore, our results do not support $\mathrm{H} 2$.

Regarding the direction of EM, the coefficient of Combined_Score is positive and statistically significant for both groups of companies, suggesting that regardless of the sustainability scores, when companies practice EM, they do it to increase earnings. 
Table 4. Corporate Social Responsibility and Earnings Management: Level of CSR.

\begin{tabular}{|c|c|c|c|c|}
\hline \multirow[b]{2}{*}{ Variables } & \multicolumn{2}{|c|}{ Panel A-CSR bellow Mean } & \multicolumn{2}{|c|}{ Panel B-CSR above Mean } \\
\hline & (1) AccDis_Abs & (2) AccDis & (3) AccDis_Abs & (4) AccDis \\
\hline \multirow[t]{2}{*}{ Combined_Score } & $-0.2553^{* * *}$ & $0.2183 * * *$ & -0.0555 & $0.1623^{* * *}$ \\
\hline & $(-4.406)$ & $(3.606)$ & $(-1.185)$ & $(3.081)$ \\
\hline \multirow[t]{2}{*}{ Growth } & $0.0882^{* * *}$ & $-0.1043^{* * *}$ & 0.0166 & 0.0007 \\
\hline & $(2.637)$ & $(-2.981)$ & $(0.734)$ & $(0.029)$ \\
\hline \multirow[t]{2}{*}{ Size } & $-0.1082^{* * *}$ & $0.1497 * * *$ & $-0.0732^{* * *}$ & $0.1333 * * *$ \\
\hline & $(-14.342)$ & $(18.984)$ & $(-8.359)$ & $(13.525)$ \\
\hline \multirow[t]{2}{*}{ Lev } & $-0.0859 * *$ & $0.1210^{* * *}$ & -0.0237 & $0.1448^{* * *}$ \\
\hline & $(-2.390)$ & (3.223) & $(-0.877)$ & $(4.768)$ \\
\hline \multirow[t]{2}{*}{ ROA } & $0.5632^{* * *}$ & $-0.8640^{* * *}$ & 0.0385 & $-0.4752 * * *$ \\
\hline & $(6.296)$ & $(-9.242)$ & $(0.519)$ & $(-5.689)$ \\
\hline \multirow[t]{2}{*}{ BIG4 } & -0.0261 & 0.0277 & 0.0022 & -0.0048 \\
\hline & $(-1.342)$ & $(1.365)$ & $(0.150)$ & $(-0.287)$ \\
\hline \multirow[t]{2}{*}{ Constant } & $0.9507^{* * *}$ & $-1.0293^{* * *}$ & $0.6400^{* * *}$ & $-0.9440 * * *$ \\
\hline & $(13.079)$ & $(-13.550)$ & $(8.847)$ & $(-11.597)$ \\
\hline Observations & 1807 & 1807 & 1637 & 1762 \\
\hline Adjusted R2 & 0.2286 & 0.3407 & 0.0856 & 0.2412 \\
\hline F-test & 18.84 & 32.11 & 25.72 & 18.33 \\
\hline$p$-value & 0.00000 & 0.00000 & 0.00000 & 0.00000 \\
\hline
\end{tabular}

The $t$-test statistic is in parentheses. ${ }^{* * *}$ and ${ }^{* * *}$ indicate significance level at $10 \%, 5 \%$ and $1 \%$, respectively. Detailed variable definitions are outlined in Empirical Model section.

\subsection{Discussion}

Our base results are in line with previous literature $[8-10,12,14,31,33]$ showing that firms that perform better in terms of CSR are also less prone to manage earnings. Thus, we contribute to the literature by pointing to the importance of attending a larger spectrum of stakeholders, when firms engage more in CSR activities, leads to better quality earnings and, thus, larger shareholder value as well $[7,34]$.

We also extend previous literature, reconciling mixed evidence on the relationship between CSR and EM. Previous research also argued for a positive relation between EM and CSR $[18,19]$. We explain those results by showing that they might be justified by difficult economic contexts molding them. In fact, when firm-specific financial performance or macroeconomic conditions worsen, we find that the relationship between CSR and EM inverts, as pointed by the later literature.

These results are important for investors, regulators and policymakers. They show that CSR does not mitigate linearly EM, but rather is context-dependent. Thus, external decision-makers should include this evidence when formulating decisions and producing regulation, especially in the present context with an economic crisis in the foreseeable future, after the COVID-19 pandemic outburst.

\section{Conclusions}

The practice of EM affects not only the shareholders but also stakeholders as a whole. As a result of less ethical behaviors, the company's management loses credibility [50]. In an attempt to hide less transparent financial reporting decisions, managers may embrace socially responsible projects [18]. Therefore, the main objective of this study is to analyze the relationship between EM and CSR in the European context in terms of both EM intensity (magnitude) and direction (income-increasing or income-decreasing).

The main results suggest a negative relationship between CSR and EM intensity, that is, most socially responsible companies practice less EM and so report earnings of higher quality. In this way, CSR is seen as an ethical factor, which translates into the transparency and quality of financial reporting and, consequently, increases stakeholders' confidence. Ehsan et al. [31] state that an inverse relationship between CSR and EM predominates in the literature. Managers seek to establish strong and healthy relationships with stake- 
holders in order to serve their interests and enhance ethical and moral values against EM practices. In terms of direction, results suggest that when companies practice EM they tend to use income-increasing strategies. This result is in line with Gargouri et al. [17] and Kyaw et al. [21], who consider CSR as an explanatory factor of positive earnings.

Previous results are yet mixed, which points to additional moderating contextual factors. We run several additional analyses to have a better understanding of this topic, and the results suggest that the intensity of CSR activities, economic crisis, and economic performance play important roles in the relationship between CSR and EM.

As for the intensity of the implementation of sustainable practices, the results suggest that, for moderate levels of CSR, sustainability policies generate a mitigating effect on EM, as shown in our main analysis. However, we do not find an association between EM and CRS for companies with more intense CRS activities. These findings are consistent with previous literature that provide evidence that relationship change according to different levels of sustainable policies implemented [7]. As for the direction of EM, the results are robust, suggesting a positive association regardless of investment in CSR, suggesting that when socially responsible companies practice EM they tend to adopt income-increase strategies.

In terms of the role of economic crises, results indicate that, in periods of crisis, more sustainable firms practice not only more EM, but also income-decreasing EM. This result is in line with the findings of Kyaw et al. [21] that argue that CSR serves as a tool to hide EM practices. It seems that during crisis years, companies with more CSR activities practice more EM than in boom years, which combining with the lower stakeholder scrutiny in unfavorable macroeconomic periods, suggest that socially responsible companies take the opportunity to "clean up" (i.e., decrease) their accounting numbers in order to perform better in subsequent years.

Similar results are obtained when analyzing the role of a company's financial performance. Indeed, in periods of negative financial performance (losses), the relationship between CSR and EM is also positive, and managers tend to decrease their results even more. When companies have economic losses, managers hide behind sustainable practices to practice more EM, justifying the allocation of costs by the implementation of CSR practices.

This work is important and contributes to research for several reasons. First, it shows that when economic activity is running normally, the relationship between CSR and EM is negative, where sustainable practices translate into good ethical behavior by managers. However, in periods of economic difficulty, whether due to external or internal factors, CSR is used opportunistically by companies, by hiding EM practices behind sustainable policies.

In this sense, the results are important for the academic literature for the novelty that this research emanates from by studying the relationship between CSR and EM under unfavorable economic conditions.

For regulators and investors, these results suggest that the relationship between CSR and EM is not fully ethical as it seems, given that managers use CSR opportunistically in periods of economic difficulty. In order to harmonize and improve the effectiveness of governance policies, particularly in European economies, regulators should reconsider the different weightings that make up the ESG score so that it reflects a more ethical and less opportunistic image of management, with regard to the concealment of EM, and be useful and relevant for the formulation of European policies related to sustainability.

The main limitation of this study relates to the CSR measure. Sustainability measurement is subjective [31], and the same measure can be calculated in different ways depending on the global geographical area $[10,17,21]$. Despite this, we use one of the most used measures in the literature, which translates into comparable results with extant literature. By the same token, it is difficult to measure EM because managers' intentions are unobservable [51]. 
Author Contributions: Conceptualization, all authors; methodology, all authors; software, T.G. and A.F.; validation, all authors; formal analysis, all authors; investigation, all authors; resources, T.G. and C.G.; data curation, T.G. and A.F.; writing—original draft preparation, C.G. and A.F.; writing-review and editing, T.G. and C.G.; visualization, all authors; supervision, T.G.; project administration, T.G.; funding acquisition, T.G. and C.G. All authors have read and agreed to the published version of the manuscript.

Funding: This research was funded by the FCT—Fundação para a Ciência e Tecnologia (Portugal), grant number UID/04521/2021, via Advance/CSG.

Data Availability Statement: Restrictions apply to the availability of these data. Data were obtained from Refinitiv Eikon (Thomson Reuters Asset4) and from Bureau Van Dijk's Amadeus and are available from the authors with their permission.

Conflicts of Interest: The authors declare no conflict of interest.

\section{Appendix A. Sample Composition}

Table A1. Sample composition by country.

\begin{tabular}{ccc}
\hline Country & Observations & Percentage (\%) \\
\hline Austria & 39 & $1.13 \%$ \\
Belgic & 18 & $0.52 \%$ \\
Czech Republic & 14 & $0.41 \%$ \\
Denmark & 48 & $1.39 \%$ \\
Finland & 94 & $2.73 \%$ \\
France & 529 & $15.36 \%$ \\
Germany & 487 & $14.14 \%$ \\
Greece & 55 & $1.60 \%$ \\
Ireland & 68 & $1.97 \%$ \\
Italy & 174 & $5.05 \%$ \\
Netherlands & 12 & $0.35 \%$ \\
Norway & 60 & $1.74 \%$ \\
Poland & 19 & $0.55 \%$ \\
Portugal & 8 & $0.23 \%$ \\
Spain & 167 & $4.85 \%$ \\
Sweden & 203 & $5.89 \%$ \\
United Kingdom & 1449 & $42.07 \%$ \\
\hline
\end{tabular}

Table A2. Sample composition by industry.

\begin{tabular}{lcc}
\hline \multicolumn{1}{c}{ Industry (Nace Rev.2) } & Observations & Percentage (\%) \\
\hline B.-Mining and quarrying & 170 & $4.94 \%$ \\
C.-Manufacturing & 807 & $23.43 \%$ \\
D.-Electricity, gas, steam and air conditioning supply & 119 & $3.46 \%$ \\
F.-Construction & 189 & $5.49 \%$ \\
G.-Wholesale and retail trade; repair of motor vehicles & 335 & $9.73 \%$ \\
and motorcycles & 160 & $4.65 \%$ \\
H.-Transportation and storage & 109 & $3.16 \%$ \\
I.-Accommodation and food service activities & 317 & $9.20 \%$ \\
J.-Information and communication & 118 & $3.43 \%$ \\
L.-Real estate activities & 987 & $28.66 \%$ \\
M.-Professional, scientific and technical activities & 113 & $3.28 \%$ \\
N.-Administrative and support service activities & 20 & $0.58 \%$ \\
S.-Other service activities & 3444 & $100 \%$ \\
Total & & \\
\hline
\end{tabular}




\section{References}

1. European Commission. Corporate Social Responsibility, Responsible Business Conduct, and Business \& Human Rights-Overview of Progress. 2019. Available online: http:/ / ec.europa.eu/ (accessed on 29 July 2019).

2. Dechow, P.M. Accounting earnings and cash flows as measures of firm performance. J. Account. Econ. 1994, 18, 3-42. [CrossRef]

3. Francis, J.; Schipper, K.; Vincent, L. The Relative and Incremental Explanatory Power of Earnings and Alternative (to Earnings) Performance Measures for Returns. Contemp. Account. Res. 2003, 20, 121-164. [CrossRef]

4. Degeorge, F.; Patel, J.; Zeckhauser, R. Earnings Management to Exceed Thresholds. J. Bus. 1999, 72, 1-33. [CrossRef]

5. Schipper, K. Earnings management. Account. Horiz. 1989, 3, 91-102.

6. Kaplan, S.E. Ethically related judgments by observers of earnings management. J. Bus. Ethics 2001, 32, 285-298. [CrossRef]

7. Chih, H.L.; Shen, C.H.; Kang, F.C. Corporate social responsibility, investor protection, and earnings management: Some international evidence. J. Bus. Ethics 2008, 79, 179-198. [CrossRef]

8. Calegari, M.F.; Chotigeat, T.; Harjoto, M.A. Corporate social responsibility and earnings reporting. J. Curr. Res. Glob. Bus. 2010, 13, 1-14.

9. Hong, Y.; Andersen, M.L. The relationship between corporate social responsibility and earnings management: An exploratory study. J. Bus. Ethics 2011, 104, 461-471. [CrossRef]

10. Kim, Y.; Park, M.S.; Wier, B. Is earnings quality associated with corporate social responsibility? Account. Rev. 2012, 87, 761-796. [CrossRef]

11. Choi, B.B.; Lee, D.; Park, Y. Corporate Social Responsibility, Corporate Governance and Earnings Quality: Evidence from Korea. Corp. Gov. Int. Rev. 2013, 21, 447-467. [CrossRef]

12. Pyo, G.; Lee, H.Y. The association between corporate social responsibility activities and earnings quality: Evidence from donations and voluntary issuance of CSR reports. J. Appl. Bus. Res. 2013, 29, 945-962. [CrossRef]

13. Scholtens, B.; Kang, F.C. Corporate social responsibility and earnings management: Evidence from Asian economies. Corp. Soc. Responsib. Environ. Manag. 2013, 20, 95-112. [CrossRef]

14. Bozzolan, S.; Fabrizi, M.; Mallin, C.A.; Michelon, G. Corporate social responsibility and earnings quality: International evidence. Int. J. Account. 2015, 50, 361-396. [CrossRef]

15. Gonçalves, T.; Gaio, C.; Costa, E. Committed vs opportunistic corporate and social responsibility reporting. J. Bus. Res. 2020, 115, 417-427. [CrossRef]

16. Cho, E.; Chun, S. Corporate social responsibility, real activities earnings management and corporate governance: Evidence from Korea. Asia-Pac. J. Account. Econ. 2016, 23, 400-431. [CrossRef]

17. Gargouri, R.M.; Shabou, R.; Francoeur, C. The relationship between corporate social performance and earnings management. Can. J. Adm. Sci. Rev. Can. Des Sci. De L'administration 2010, 27, 320-334. [CrossRef]

18. Prior, D.; Surroca, J.; Tribó, J.A. Are socially responsible managers really ethical? Exploring the relationship between earnings management and corporate social responsibility. Corp. Gov. Int. Rev. 2008, 16, 160-177. [CrossRef]

19. Salewski, M.; Zülch, H. The Association between Corporate Social Responsibility (CSR) and Earnings Quality-Evidence from European Blue Chips. SSRN Electron. J. 2012. [CrossRef]

20. Yip, E.; Van Staden, C.; Cahan, S. Corporate social responsibility reporting and earnings management: The role of political costs. Australas. Account. Bus. Financ. J. 2011, 5, 17-34.

21. Kyaw, K.; Olugbode, M.; Petracci, B. The role of the institutional framework in the relationship between earnings management and corporate social performance. Corp. Soc. Responsib. Environ. Manag. 2017, 24, 543-554. [CrossRef]

22. Gonçalves, T.; Pimentel, D.; Gaio, C. Risk and performance of European green and conventional funds. Sustainability 2021, 13, 4226. [CrossRef]

23. Jones, J.J. Earnings Management during Import Relief Investigations. J. Account. Res. 1991, 29, 193. [CrossRef]

24. Kothari, S.P.; Leone, A.J.; Wasley, C.E. Performance matched discretionary accrual measures. J. Account. Econ. 2005, 39, 163-197. [CrossRef]

25. Liu, J.; Nissim, D.; Thomas, J. Equity valuation using multiples. J. Account. Res. 2002, 40, 135-172. [CrossRef]

26. Graham, J.R.; Harvey, C.R.; Rajgopal, S. The economic implications of corporate financial reporting. J. Account. Econ. 2005, 40, 3-73. [CrossRef]

27. Gonçalves, T.; Gaio, C.; Lélis, C. Accrual mispricing: Evidence from European sovereign debt crisis. Res. Int. Bus. Financ. 2020, 52, 101111. [CrossRef]

28. Gonçalves, T.; Coelho, G. Earnings management during mergers and acquisitions—European evidence. Eur. J. Econ. Financ. Adm. Sci. 2019, 102, 22-43. [CrossRef]

29. Gaio, C.; Gonçalves, T.; Azevedo, R. Earnings management: Evidence of listed and unlisted companies in europe. Innovar 2020, 30, 77-90. [CrossRef]

30. Činčalová, S.; Hedija, V. Firm Characteristics and Corporate Social Responsibility: The Case of Czech Transportation and Storage Industry. Sustainability 2020, 12, 1992. [CrossRef]

31. Ehsan, S.; Abbas, Q.; Nawaz, A. An inquiry into the Relationship between Earnings' Management, Corporate Social Responsibility and Corporate Governance. J. Soc. Sci. 2018, 11, 1-14.

32. Shen, C.H.; Chih, H.L. Investor protection, prospect theory, and earnings management: An international comparison of the banking industry. J. Bank. Financ. 2005, 29, 2675-2697. [CrossRef] 
33. Choi, T.H.; Pae, J. Business ethics and financial reporting quality: Evidence from Korea. J. Bus. Ethics 2011, $103,403-427$. [CrossRef]

34. Fischer, M.; Rosenzweig, K. Attitudes of students and accounting practitioners concerning the ethical acceptability of earnings management. J. Bus. Ethics 1995, 14, 433-444. [CrossRef]

35. Cheney, G.; McMillan, J.J. Organizational rhetoric and the practice of criticism. J. Appl. Commun. Res. 1990, 18, 93-114. [CrossRef]

36. Waddock, S.A.; Graves, S.B. The corporate social performance-financial performance link. Strateg. Manag. J. 1997, 18, 303-319. [CrossRef]

37. Roman, R.M.; Hayibor, S.; Agle, B.R. The relationship between social and financial performance: Repainting a portrait. Bus. Soc. 1999, 38, 109-125. [CrossRef]

38. Orlitzky, M.; Schmidt, F.L.; Rynes, S.L. Corporate social and financial performance: A meta-analysis. Organ. Stud. 2003, 24, 403-441. [CrossRef]

39. Roychowdhury, S. Earnings management through real activities manipulation. J. Account. Econ. 2006, 42, 335-370. [CrossRef]

40. Cohen, D.A.; Dey, A.; Lys, T.Z. Real and accrual-based earnings management in the pre-and post-Sarbanes-Oxley periods. Account. Rev. 2008, 83, 757-787. [CrossRef]

41. Dechow, P.M.; Sloan, R.G.; Sweeney, A.P. Causes and consequences of earnings manipulation: An analysis of firms subject to enforcement actions by the SEC. Contemp. Account. Res. 1996, 13, 1-36. [CrossRef]

42. Press, E.G.; Weintrop, J.B. Accounting-based constraints in public and private debt agreements: Their association with leverage and impact on accounting choice. J. Account. Econ. 1990, 12, 65-95. [CrossRef]

43. Carlson, S.J.; Bathala, C.T. Ownership differences and firms' income smoothing behaviour. J. Bus. Financ. Account. 1997, 24, 179-196. [CrossRef]

44. Becker, C.L.; DeFond, M.L.; Jiambalvo, J.; Subramanyam, K.R. The effect of audit quality on earnings management. Contemp. Account. Res. 1998, 15, 1-24. [CrossRef]

45. Skinner, D.J.; Sloan, R.G. Earnings surprises, growth expectations, and stock returns or don't let an earnings torpedo sink your portfolio. Rev. Account. Stud. 2002, 7, 289-312. [CrossRef]

46. Van Tendeloo, B.; Vanstraelen, A. Earnings management and audit quality in Europe: Evidence from the private client segment market. Eur. Account. Rev. 2008, 17, 447-469. [CrossRef]

47. Chen, C.L.; Huang, S.H.; Fan, H.S. Complementary association between real activities and accruals-based manipulation in earnings reporting. J. Econ. Policy Reform. 2012, 15, 93-108. [CrossRef]

48. Zamri, N.; Rahman, R.A.; Isa, N.S.M. The impact of leverage on real earnings management. Procedia Econ. Financ. 2013, 7, 86-95. [CrossRef]

49. Filip, A.; Raffournier, B. Financial crisis and earnings management: The European evidence. Int. J. Account. 2014, 49, 455-478. [CrossRef]

50. Rowley, T.; Berman, S. A brand new brand of corporate social performance. Bus. Soc. 2000, 39, 397-418. [CrossRef]

51. Dechow, P.M.; Ge, W.; Schrand, C. Understanding earnings quality: A review of the proxies, their determinants and their consequences. J. Account. Econ. 2010, 50, 344-401. [CrossRef] 